\title{
Identification and Purification of Antioxidant Peptides from Lentils (Lens Culinaris) Hydrolysates
}

\author{
Muhammad Jamirul Ashad Zehadi, Kingsley Masamba, Yue Li, Maoshen Chen, Xuemei Chen, \\ Hafiz Rizwan Sharif, Fang Zhong
}

State Key Laboratory of Food Science and Technology, School of Food Science and Technology, Jiangnan University, Wuxi, Jiangsu, Peoples Republic China

\section{Email address: \\ fzhong@jiangnan.edu.cn (Fang Zhong)}

\section{To cite this article:}

Muhammad Jamirul Ashad Zehadi, Kingsley Masamba, Yue Li, Maoshen Chen, Xuemei Chen, Hafiz Rizwan Sharif, Fang Zhong. Identification and Purification of Antioxidant Peptides from Lentils (Lens Culinaris) Hydrolysates. Journal of Plant Sciences.

Vol. 3, No. 3, 2015, pp. 123-132. doi: 10.11648/j.jps.20150303.13

\begin{abstract}
Powder derived from Lentils was hydrolyzed sequentially using five different enzymes and their combinations for production of antioxidant peptide. For identifying antioxidant peptides, Lentils hydrolysate was fractionated using Ultra filtration and size exclusion chromatography (Superdex Peptide 10/300 GL) methods. The lentils peptide and its fractions demonstrated antioxidant activities as revealed from studies using a $\beta$-carotene-linoleate model system, hydroxyl radicalscavenging, the DPPH radical-scavenging activity assay, and a reducing power evaluation. Molecular characteristics of individual Lentils protein was investigated using sodium dodecyl sulfate polyacrylamide gel electrophoresis (SDS-PAGE). The results demonstrated that Lentils peptide fraction III exhibited the highest antioxidant activity compared to the other Lentils Fraction. The molecular weight and sequence were identified by LC-MS analysis as $587.31 \mathrm{Da}$ and the amino acid sequence was as follows: Ala- Leu- Gly- Pro- Val- Met.
\end{abstract}

Keywords: Lentils, Lentils Peptide Hydrolysate, Antioxidant Properties, Sdspage

\section{Introduction}

Lentil (Lens culinaris) is an important pulse crop in America Australia, Afghanistan, Bangladesh, Canada, Egypt, Ethiopia, Egypt, India, Iraq, Iran, Morocco, Nepal, Pakistan, Sudan, Syria, Turkey and Tunisia. The annual production of Lentils accumulated to is $495 \mathrm{Ktons}$ in the year of for 2013 (1).Lentil is a powerhouse of nutrition and a good source of potassium, calcium, zinc, niacin and vitamin $\mathrm{K}$, but are also particularly rich in dietary fiber, lean protein, folate and iron. Lentils need short time for cooking compared with other pulses and its higher protein level with a lower level of antinutritional factors, make lentils very suitable for human consumption(2).

Reactive oxygen and nitrogen species (RONS) is scavenged by natural antioxidant from plant endogenous to food which formed energy supplier, detoxification, immune function and chemical signaling superoxide anion, hydroxyl radical and hydrogen peroxide, are highly reactive and potentially damaging transient chemical species (3), researchers have suggested that these may be of great importance in preventing the onset of oxidative diseases (4)

The antioxidant activity responsible compounds could be isolated and used for preventing and treating of free radical related disorders (5). Lentils are a leguminous seed that have high levels of natural antioxidants $(6,7,8)$. Lentils has the highest antioxidant capacity when measured as 2,2-diphenyl1-picrylhydrazyl (DPPH) free radical scavenging capacity in comparison with green pea, yellow pea and chickpea(9). 1, 1Diphenyl-2-picryl-hydrazyl is a stable free radical which has an unpaired valence electron at one atom of Nitrogen Bridge (10). Repeatedly ingestion of legumes, as part of healthy diet, has been conversely conjoined with cardiovascular disease (CVD) (11), colon cancer, diabetes (12).

The in vitro digestion of the lentil proteins by pepsin/trypsin/ $\alpha$-chymotrypsin, alcalase/flavourzyme and papain has been reported to significantly reduce the bile salt binding capacity compared to the undigested samples except in the case of sodium deoxycholate where no significant differences in bile salt binding were observed before and after hydrolysis (13). Recently, some study findings have shown that the lentils hydrolysate peptide has angiotensin I- 
converting enzyme, Antioxidant and antihypertensive properties $[11,13,14]$

The aim of this current study was to determine the effect of using different enzymes in lentil protein hydrolysis on antioxidant activities and to further determine the bioactive peptides based on molecular weight distribution. In addition, purification of lentil peptides was also carried out.

\section{Materials and Methods}

\subsection{Materials}

Lentils used in this study were purchased from a super market in Bangladesh and later transported to People's Republic of China where further analysis was conducted. Trypsin, Alcalase and Flavorzyme were purchased from a shanghai canspec scientific instruments co. ltd. DPPH was obtained from TCI, Shanghai, China. Pepsin, papain, tertButylhydroquinone (TBHQ) and ascorbic acid were all purchased from Sigma Chemical Co. (China). All the other solvents and chemicals used were of analytical grade.

\subsection{Protein Extraction}

Extraction of water-soluble protein from Lentils was prepared using the extraction method as described by Suliman[15] with minor modifications. Lentils were ground into powder using a blender. The powder was then soaked in water in the ratio of $1: 15(\mathrm{w}: \mathrm{w})$. The solution was homogenized for 1 hour at room temperature after the $\mathrm{pH}$ was adjusted to 8.5 using $0.5 \mathrm{M} \mathrm{NaOH}$. It was further homogenized for 30 minutes and was then left for 5 hours. The solution was then centrifuged at $4500 \times \mathrm{g}$ for $10 \mathrm{mins}$ and the clear supernatant was collected. The $\mathrm{pH}$ of the collected supernatant was adjusted to 4.5 using $1 \mathrm{M} \mathrm{HCl}$ and was left for 30 mins at room temperature. Later, the solution was centrifuged at $4500 \times \mathrm{g}$ for $10 \mathrm{mins}$ and the pellet was washed with water and centrifuged again at $4500 \times \mathrm{g}$ for 10 mins. The collected protein was later freeze dried.

\subsection{Protein Analysis}

The total nitrogen content of the sample was estimated by the kjeldahl method [16] and the nitrogen conversion factor of 6.25.protein percentage was 92\%. Lowery method [17] and Bradford Protein Assay [18] were also used for determining the protein content in liquid form.

\subsection{Moisture Content}

The moisture content was determined using the method developed by Nielsen [19]. Samples were taken out of the refrigerator and brought to room temperature before they were exposed to microwave heating. A sample of approximately $2.5 \mathrm{~g}$ was weighed in a paper. Then the samples were transferred into crucible. The crucibles were placed in a micro-oven. The temperature of the micro-oven was $113^{\circ} \mathrm{C}$.After six hours the samples were placed into the micor-oven. The crucibles and sample were taken out, weighed for four different times. The sample is heated under specified conditions and the loss of weight is used to calculate the moisture content of the sample

$$
\% \text { of Moisture content }=\frac{w t \text { of } \text { water in the sample }}{w \text { t of wet sample }} \times 100
$$

\subsection{Preparation of Lentils Hydrolysates}

Lentils hydrolysates were prepared according to the method described by Cabanillas [20] under controlled hydrolysis conditions of $\mathrm{pH}$, temperature, enzyme concentration and stirring speed using five enzymes and their combinations. Each enzyme was added separately to the lentil protein concentrate slurry using a specific enzyme/substrate $(\mathrm{E} / \mathrm{S})$ ratio $(\mathrm{w} / \mathrm{w})$ (based on protein content of the concentrates) and digested for a specific time while maintaining the optimal temperature and $\mathrm{pH}$ of the enzyme. Briefly, Lentil protein was suspended in distilled water $(0.5$ $\mathrm{g} / 20 \mathrm{~mL})$ and added under optimal conditions $\left(55^{\circ} \mathrm{C}, 1 \mathrm{~h}\right.$, and $\mathrm{pH}$ 8.0).In order to dissolve the protein at the beginning, the $\mathrm{pH}$ was set at 11 using $0.5 \mathrm{M} \mathrm{NaOH}$. After one hour, the $\mathrm{pH}$ was adjusted using $1 \mathrm{M}$ HCL. The tryptic digestion (E/S: 1/25) was conducted for 3 to $24 \mathrm{~h}$ at $37^{\circ} \mathrm{C}$ and $\mathrm{pH} 6.5$. The Alcalase digestion (E/S: 1/8) was conducted for $30 \mathrm{~min}$ to $120 \mathrm{~min}$ at $55 \mathrm{C}$ and $\mathrm{pH}$ 8. The pepsin digestion (E/S: 1/100) was conducted at $1 \mathrm{~h}$ to $3 \mathrm{~h}$ at $37^{\circ} \mathrm{C}$ and $\mathrm{pH}$ 2. The papain digestion (E/S: $1 / 25)$ was conducted for $15 \mathrm{~min}$ to $60 \mathrm{~min}$ at $37^{\circ} \mathrm{C}$ and $\mathrm{pH} 6.5$ and the flavorzyme digestion (E/S: $\left.1 / 10\right)$ was conducted for $30 \mathrm{~min}$ to $120 \mathrm{~min}$ at $37^{\circ} \mathrm{C}$ and $\mathrm{pH} 7 . \mathrm{LH}$ was hydrolysed using sequential digestion with
Trypsin/pepsin (TP), Trypsin/Alcalase (TA), Alcalase/Flavourzyme (AF), Alcalase/Pepsin (AP), Pepsin/Papain (PP).The hydrolysate was subsequently transferred to a water bath $\left(90^{\circ} \mathrm{C}\right)$ for 10 min to inactivate the enzyme. After cooling, the supernatant was obtained by centrifugation at $4500 \times \mathrm{g}$ for $10 \mathrm{~min}$.

\subsection{Determination of Total Phenolic Compound of Lentils}

The total phenolic content was determined by the FolinCiocalteu colorimetric method according to Sarac [21]. 200 $\mathrm{mL}$ of lentils extract solution was prepared at a concentration of $1 \mathrm{mg} / \mathrm{mL}$ and transferred into test tube. $5 \mathrm{~mL}$ of $0.2 \mathrm{~N}$ Folin-Ciocalteu reagents was added and the test tube was shaken. The mixture was allowed to stand at room temperature for 3 mins.then $10 \mathrm{ml}$ of $7 \%(\mathrm{w} / \mathrm{v})$ sodium carbonate was added, mixed gently and made the volume to $25 \mathrm{~mL}$ with distilled water. The test tube was incubated for one and half hours in dark with intermittent shaking. . The absorbance of all samples was measured at $760 \mathrm{~nm}$.

Content of phenolic compound was determined as $\mathrm{mg}$ gallic acid equivalents per gram of extract $(\mathrm{mg} / \mathrm{g}$ GAE extract) using the following linear equation based on the calibration curve: $\mathrm{A}=0.294 \mathrm{C}, \mathrm{R}^{2}=0.996$ where $\mathrm{A}$ is the 
absorbance and $\mathrm{C}$ gallic acid equivalents.

\subsection{Amino Acid Composition}

Amino acid compositions of three fractions of lentils were determined by High Performance Liquid Chromatography (HPLC) according to (22).The samples were hydrolyzed with $6 \mathrm{~N} \mathrm{HCL}$ for $24 \mathrm{~h}$ at $110^{\circ} \mathrm{C}$ in sealed vials maintained under inert atmosphere $\left(\mathrm{N}_{2}\right)$. Amino acid composition was determined using an HPLC system (Agilent 1100 series) and a reverse phase column $((250 * 4.6) \mathrm{mm} 5 \mu \mathrm{m}$ ODS HYPERSIL) at $40{ }^{\circ} \mathrm{C}$. The solvent used was sodium acetate (25 mM), containing Triethylamine $(0.02 \%)$ at $\mathrm{pH} 7.20 \pm 0.05$ in acetonitrile at a flow rate of $1.0 \mathrm{~mL} / \mathrm{min}$. Tryptophan was determined at $338 \mathrm{~nm}, 262 \mathrm{~nm}$ (Pro,Hypro) after basic hydrolysis with $4 \mathrm{M} \mathrm{NaOH}$ for $4 \mathrm{~h}$ at $110^{\circ} \mathrm{C}$.

\subsection{Determination of Antioxidant Activity}

\subsubsection{Dpph Radical-Scavenging Activity}

DPPH radical-scavenging activity was determined using the method of Sharma [10] and Xiaohong (23) with minor modifications. Two milliliter of the Lentils protein hydrolysate solution in distilled water was mixed with two $\mathrm{mL}$ of $0.1 \mathrm{mmol} / \mathrm{L} \mathrm{DPPH}$ in methanol. The mixture was then vigorously mixed and allowed to stand at room temperature in the dark for 30 mins. The absorbance of the mixture was measured at $517 \mathrm{~nm}$ using a spectrophotometer. The DPPH control was conducted in the same manner, but ethanol was used instead of DPPH. The sample control group contained distilled water instead of the sample. The range of accuracy for spectrophotometric measurements falls within an absorbance of $0.221-0.698[10]$.

DPPH radical-scavenging activity was calculated as follows:

DPPH radical scavenging activity $\%=\left(1-\frac{A_{t}-A_{b}}{A_{c}}\right) \times 100$,

Where $A_{t}$ is the absorbance of sample; $A_{b}$ is the absorbance of the sample control; and $A_{c}$ is the absorbance of the DPPH control.

\subsubsection{Antioxidant Activity as Determined by B-Carotene- Linoleate Model System}

The antioxidant activity of the lentil crude extracts was determined in an emulsion system according to (8). Briefly, methanolic solutions $(0.2 \mathrm{~mL})$ containing $2 \mathrm{mg}$ of the crude extract was pipetted into a series of test tubes to which $5 \mathrm{~mL}$ of a prepared emulsion of linoleic acid and $\beta$-carotene stabilized by Tween 40 were added. Immediately after addition of the emulsion, the zero-time absorbance reading at $470 \mathrm{~nm}$ was recorded for each tube. Samples were held in a water bath at $50{ }^{\circ} \mathrm{C}$ and their absorbance values were recorded over a 120-min period at 15-min intervals. The assay was replicated three times for each sample and means \pm standard deviation were reported (8).

\subsection{Reducing Power}

The reducing power of the hydrolysates was determined using Wang's [24] method with minor modifications. The sample solution $(4 \mathrm{~mL})$ in ionized water with a solid concentration in the range of $2 \mathrm{mg} / \mathrm{mL}$ was mixed with 2.5 $\mathrm{mL}$ of $0.2 \mathrm{~mol} / \mathrm{L}$ phosphate buffer $(\mathrm{pH}=6.6)$ and $2.5 \mathrm{~mL}$ of $1 \%$ potassium ferric cyanide solution. The mixture was then kept in a water bath at $50{ }^{\circ} \mathrm{C}$ for $20 \mathrm{~min}$. The resulting solution was cooled rapidly, and then mixed with $2.5 \mathrm{~mL}$ of $10 \%$ TCA $(\mathrm{m} / \mathrm{V})$, and centrifuged at $3000 \mathrm{rpm}$ for $10 \mathrm{~min}$. Finally, the supernatant $(2.5 \mathrm{~mL})$ was mixed with $2.5 \mathrm{~mL}$ of distilled water and $0.5 \mathrm{~mL}$ of $0.1 \%$ ferric chloride solution. The absorbance of the resulting mixture was measured at $700 \mathrm{~nm}$ after the reducing reaction for $10 \mathrm{~min}$. High absorbance indicates strong reducing power.

\subsection{Hydroxyl Radical-Scavenging Activity}

The hydroxyl radical-scavenging assay was determined using the method as described by Yanhong [25] with minor modifications. Both 1, 10-phenanthroline $(2.5 \mathrm{mM} / \mathrm{L})$ and $\mathrm{FeSO}_{4}(2.5 \mathrm{mM} / \mathrm{L})$ were dissolved in phosphate buffer $(\mathrm{pH}$ 7.4) and mixed thoroughly. $30 \% \mathrm{H}_{2} \mathrm{O}_{2}(20 \mathrm{mM} / \mathrm{L})$ and $\mathrm{LPH}$ fractions $(1.5 \mathrm{mg} / \mathrm{ml})$ were added. The mixture was incubated at $37^{\circ} \mathrm{C}$ for $60 \mathrm{~min}$, and the absorbance was measured at 536 $\mathrm{nm}$. Results were determined using the following equation:

$$
\text { Antioxidant Activity }=\frac{A_{s}-A_{o}}{A_{c}-A_{o}} \times 100
$$

Where $A_{S}$, absorbance of the sample; Ao, absorbance of control solution containing 1, 10-phenanthroline, $\mathrm{FeSO}_{4}$ and $\mathrm{H}_{2} \mathrm{O}_{2}$; Ac, absorbance of blank solution containing 1, 10phenanthroline and $\mathrm{FeSO}_{4}$.

\subsection{Sds-Polyacrylamide Gel Electrophoresis}

SDSPAGE was carried out using the technique described by Laemmli [26] with a $4 \%$ stacking gel and a $7.5 \%$ resolution gel. Electrophoresis was carried out at $70 \mathrm{~V}$ to 120 $\mathrm{V}$ for Tris-HCl SDS-PAGE. The running buffers were $0.1 \mathrm{M}$ Tris- $\mathrm{HCl}, 0.1 \%(\mathrm{w} / \mathrm{v})$ SDS, for the SDS-PAGE of the protein concentrates and $0.1 \mathrm{M}$ Tris- $\mathrm{HCl}, 0.1 \mathrm{M}$ tricine, with $0.1 \%$ $(w / v)$ SDS, for the SDS-PAGE of the hydrolysates [27]. Sample solutions $(30 \mu \mathrm{L})$ were prepared from $10 \mathrm{mg}$ freezedried protein extract or hydrolysate dissolved in $10 \mu \mathrm{L}$ sample buffer (distilled water, $0.5 \mathrm{M} \mathrm{Tri-} \mathrm{HCl} \mathrm{pH} \mathrm{6.8,}$ glycerol, $10 \%$ SDS, $1 \%$ bromophenol blue and $\beta$ mercaptoethanol) heated at $98{ }^{\circ} \mathrm{C}$ for $5 \mathrm{~min}$, then applied to the sample wells. The standard protein marker (Precision Plus Protein Standard, Bio-Rad, USA) which contained myosin $(250,000 \quad$ Da), $\beta$-galactosidase $(150,000 \quad \mathrm{Da})$, phosphorylase b (100,000 Da), serum albumin $(75,000 \mathrm{Da})$, ovalbumin $(50,000 \mathrm{Da})$, carbonic anhydrase $(37,000 \mathrm{Da})$, trypsin inhibitor $(25,000 \mathrm{Da})$, lysozyme $(20,000 \mathrm{Da})$ and aprotinin $(10,000 \mathrm{Da})$, was used to prepare a standard curve for molecular weight estimation [28].

\subsection{Peptide Fractionation by Ultra Filtration}

Lentils Hydrolysate was fractionated consecutively through UF membranes [29] having MWCO of $5 \mathrm{kDa}$, $3 \mathrm{kDa}$ and $1 \mathrm{kDa}$. The first UF separation was performed 
using a regenerated cellulose $5 \mathrm{kDa}$-membrane (Master Flex, $88 \mathrm{~cm}^{2} * 0.11 \mathrm{M}^{2}$, Millipore Corp., Cassette Holder) at a transmembrane pressure of 5-10 bar. The permeate collected in this first stage was further ultrafiltered using a regenerated cellulose $5 \mathrm{kDa}$-membrane. This process yielded four fractions for $\mathrm{LH}$ : a retentate enriched in peptides $>5 \mathrm{kDa}$, a permeate mainly composed of peptides $<5 \mathrm{kDa}$, a second retentate enriched in peptides $5-3 \mathrm{kDa}$, and a second permeate containing peptides $>3 \mathrm{kDa}$, the third retentate enriched in peptides $3-1 \mathrm{kDa}$, and permeate containing peptides $<1 \mathrm{kDa}$ and lyophilized into powder form.

\subsection{Purification of Antioxidant Peptide}

Ultrafiltration fraction was subjected to Superdex Peptide 10/300 GL, prepacked Tricorn high-performance column for high-resolution gel filtration of peptide by using Akta Pure. Adsorbed materials were eluted with $10 \mathrm{mM}$ Tris- $\mathrm{HCl}$ Buffer (pH 7.6) [30] gradient at $0.5 \mathrm{ml} / \mathrm{min}$ flow rate, $1.05 \mathrm{psi}$ in the $280 \mathrm{~nm}$ wavelength region, All samples were clarified by centrifugation at $10000 \mathrm{~g}$ for $10 \mathrm{~min}$ followed by filtration through $0.22 \mu \mathrm{m}$ in-line filters. The column flow-through and wash fraction was first collected into a $1 \mathrm{ml}$ loop and then applied to a customized superdex peptide 10/300 GL equilibrated with storage buffer containing $10 \mathrm{mM}$ Tris$\mathrm{HCl}$.Protein was eluted with storage buffer, peaks were collected in $2 \mathrm{ml}$ fractions and analyzed by the SDS PAGE stained with coomassie Brilliant Blue R.purification of ultrafiltration fraction takes about $7 \mathrm{hrs}$. The column was washed and re-equilibrated prior to the next purification cycle. The column, tubing and loop were washed between chromatography steps to avoid cross-contamination. The final peak fractions and all solutions that could contain target protein were collected [31].

\subsection{Determination of Molecular Weight Distribution}

The lentils peptide fractions from AKTA pure filtered through a 0.45 -lm cellulose acetate filter (Millipore) before HPLC analysis. The chromatographic system comprised a HPLC system consisting of LC-10AD Vppumps, UV-VIS SPD-M10A Vp photo-diode array detector, SCL-10A Vp system controller. The samples were injected into a TSK Gel G2000SW $\mathrm{XL}(5 \mu \mathrm{m}, 7.86 \times 300 \mathrm{~mm})$. The analytical conditions for separation are described by Magdalena [32]. Briefly, the mobile phase was employed for elution: Acetonitrile / water / trifluoroacetic acid (45/55/0.1 $(\mathrm{V} / \mathrm{V})$ ). The flow rate was $0.5 \mathrm{~mL} / \mathrm{min}$ from the time 0 to $30 \mathrm{~min}$. The column was re-equilibrated between sample injections with $10 \mathrm{~mL}$ of acetonitrile and $25 \mathrm{~mL}$ of mobile phase. Diode array detection was performed by scanning over a wavelength within the range from $220 \mathrm{~nm}$ to $280 \mathrm{~nm}$ at an acquisition speed of 1 s. Cytochrome C ( MW12384 ) , Bacitracin (MW1450), Gly-Gly-Tyr-Arg ( MW451 ) , Gly-Gly-Gly ( MW189) were used as molecular weight standards. Samples were analyzed in triplicate.

\subsection{LC Mass}

To determine the molecular mass and amino acid sequence of the purified Lentils peptide, MS/MS experiments were performed [33].Approximately $5 \mathrm{ml}$ of the purified peptide solution was injected into BEH $1302.1 \times 100 \mathrm{~mm} 1.7 \mathrm{um}$ connected to the waters acquity uplc the mass spectrometer with a speed of $400 \mathrm{~mL} / \mathrm{min}$, and the molecular mass was determined by a single charged $(\mathrm{M}+\mathrm{H}){ }^{+1}$ state in the mass spectrum via the electrospray interface. The ESI nebulizing gas and auxiliary gas used high purity nitrogen. Spectra were recorded over the mass/charge $(\mathrm{m} / \mathrm{z})$ range of $150-2000$. The following parameters were used: electrospray voltage of $1700 \mathrm{~V}$; heated capillary temperature of $400^{\circ} \mathrm{C}$; the desolvation gas flow was $700 \mathrm{lit} / \mathrm{hr}$ and the cone gas flow was $50 \mathrm{lit} / \mathrm{hr}$. collision energy of 6 volts; and activation time of $30 \mathrm{~ms}$. Following molecular mass determination, the peptide was automatically selected for fragmentation, and sequence information was obtained by tandem mass spectroscopy (MS/MS) analysis. Data were processed using Masslynx (v4) software.

\section{Results and Discussions}

The total phenolic content of lentils extract measured by Folin-Ciocalteu colorimetric method was found $55 \mathrm{mg}$ $\mathrm{GAE} / \mathrm{g}$ extract. Other studies have previously reported a value of $58 \mathrm{mg} / \mathrm{gm}$ for the red lentils [8].Amino acid compositions of Lentils and Lentils hydrolysates showed in table 1.The amino acid compositions of Lentils extract indicated that it possesses high proportions of Asp and Glu, which are usually storage proteins of legumes.

Table 1. Amino Acid composition of Lentils fractions (g/100g Protein).

\begin{tabular}{llll}
\hline $\begin{array}{l}\text { Amino } \\
\text { Acids }\end{array}$ & $\begin{array}{l}\text { extrac } \\
\text { protein }\end{array}$ & $\begin{array}{l}\text { Hydrolysed } \\
\text { ultrafiltration } \\
\text { fractions }\end{array}$ & AKTA pure fractions \\
\hline asp & 10.31 & 9.98 & $1.33 \times 10^{-1}$ \\
glu & 17.50 & 17.63 & $1.28 \times 10^{-1}$ \\
ser & 3.61 & 3.50 & $6.63 \times 10^{-2}$ \\
his & 2.29 & 2.18 & $5.47 \times 10^{-2}$ \\
gly & 3.43 & 3.33 & $7.51 \times 10^{-2}$ \\
thr & 2.69 & 2.51 & $4.86 \times 10^{-2}$ \\
arg & 7.21 & 7.08 & $3.52 \times 10^{-1}$ \\
ala & 3.59 & 3.37 & $3.39 \times 10^{-1}$ \\
tyr & 2.45 & 2.26 & $7.19 \times 10^{-3}$ \\
cys-s & $3.06 \times 10^{-1}$ & $2.72 \times 10^{-1}$ & $1.82 \times 10^{-2}$ \\
val & 5.12 & 4.94 & $1.14 \times 10^{-1}$ \\
met & $8.32 \times 10^{-1}$ & $8.04 \times 10^{-1}$ & $2.44 \times 10^{-2}$ \\
phe & 5.36 & 4.66 & $1.37 \times 10^{-1}$ \\
ile & 4.97 & 4.34 & $6.67 \times 10^{-2}$ \\
leu & 8.04 & 7.15 & $1.74 \times 10^{-1}$ \\
lys & 6.44 & 6.33 & $1.01 \times 10^{-1}$ \\
total & 84.21 & 80.43 & 1.84 \\
\hline
\end{tabular}

\subsection{Sds-Page of the Lentils Protein of Different Concentration}

Results of protein composition of lentils as determined by SDS-PAGE are shown in Fig 2. The protein profile of the lentils extract can be seen in lane $1,2,3$ in different 
percentages. SDS-PAGE pattern contained five major protein bands and seven weak bands. Lentils protein concentrates showed a multitude of bands ranging in size from approximately 25-100 kDa. Electrophoretic profile shows the extract was composed of at least of seven polypeptides ranging from 25 to $100 \mathrm{kDa}$. All the concentrates showed bands in the range of $25-37$ to $38-45 \mathrm{kDa}$ corresponding to the basic and acidic subunits respectively. There are two bands that had molecular weights corresponding to $48 \mathrm{kDa}$ and $65 \mathrm{kDa}$ which probably represent the subunits of vicilin $(48 \mathrm{kDa})$ and convicilin $(63 \quad \mathrm{kDa})$, respectively[34,35,36].There are no significant differences among all the three lanes.

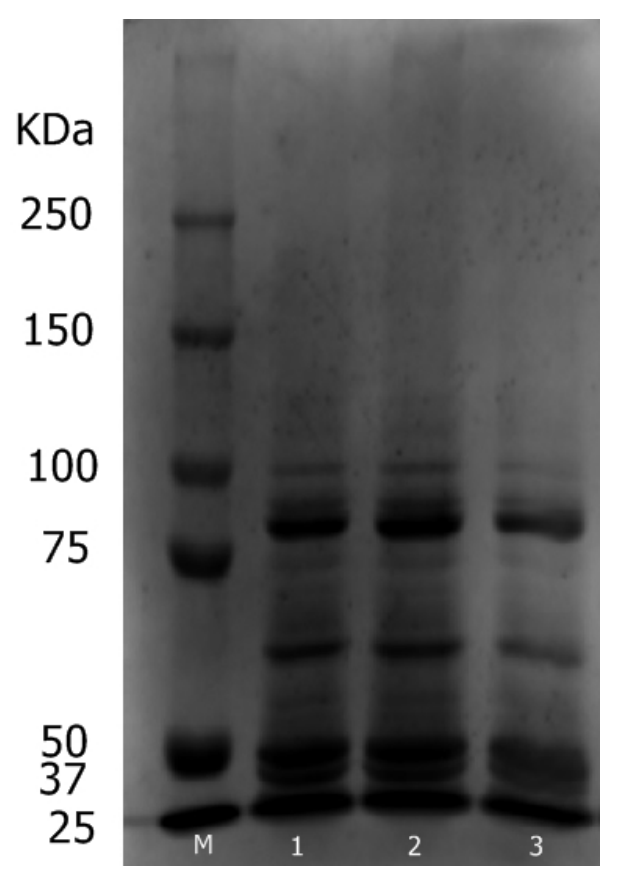

Fig. 2. SDS-PAGE separation of lentil protein in different concentrations; $1: 5 \%$ with loading buffer;2:3\% with loading buffer; $3: 1 \%$ with loading buffer.

The enzyme Alcalase prefers to cleave peptides at the interior of the polypeptide chain and it can hydrolyze into peptide which has better and nutritional characteristics than the original proteins. Alcalase also can generate bioactive peptides [36].Flavorzyme is a protease complex from
Aspergillus oryzaewith endopeptidase and exopetidase activities [23].Pepsin was found to cleave peptides that fit well into the active site. Therefore it preferentially cleaves some peptides better than others [37].Papain, a widely commercial protease in bioprocesses, used for the obvious morphology change and the enhanced catalytic efficiency indicated the practical value of the new p-CLEAs on catalysis of macromolecules [38].

\subsection{Enzymatic Hydrolysis of Lentils Protein}

Lentils proteins were hydrolyzed by using Alcalase, Flavourzyme, Pepsin, Trypsin and Papain with their identified optimum conditions for producing the antioxidant peptides. The antioxidant activity of the Lentils hydrolysates was determined using DPPD, Free radical scavenging activity, reducing power and $\beta$-carotene-linoleate model system as describe previously. In free radical scavenging activities against DPPH, pepsin and combination of pepsin-trypsin hydrolysate revealed the most potent free radical scavenging ability. SY Kim [39] previously reported that peptic hydrolysate had the highest antioxidant activity, further antioxidant lentils peptide has produced by hydrolyzing of combination of two different enzymes. Results for the analysis using DPPD are presented in Figure 1(a,b). It is evidently clear that the combined use of trypsin and pepsin had the highest antioxidant activity and the Lentils hydrolysates prepared by pepsin alone also showed high antioxidant activity.The lentils hydrolysate by pepsin and pepsin-trypsin further separated eight molecular weight groups using ultrafiltration membranes $(\mathrm{MWCO}=5,3$ and 1 $\mathrm{kDa})$ into $>5 \mathrm{kDa}, 5-3 \mathrm{kDa}, 3-1 \mathrm{kDa},<1 \mathrm{kDa}$. The antioxidant activity of the four enzymes as determined by DPPD assay showed differences as reflected in picture (c).The result indicated that the $<1 \mathrm{kDa}$ group of pepsintrypsin has the highest antioxidant activity than the other groups. After ultrafiltrating the pepsin fractions, it did not show the obvious ability to scavenge the DPPH free radical. So for further investigation, the pepsin-trypsin $<1 \mathrm{kDa}$ fraction was used. The $\mathrm{IC}_{50}$ value is $1.395 \mathrm{mg} / \mathrm{ml}$ as shown in the figure (d). 


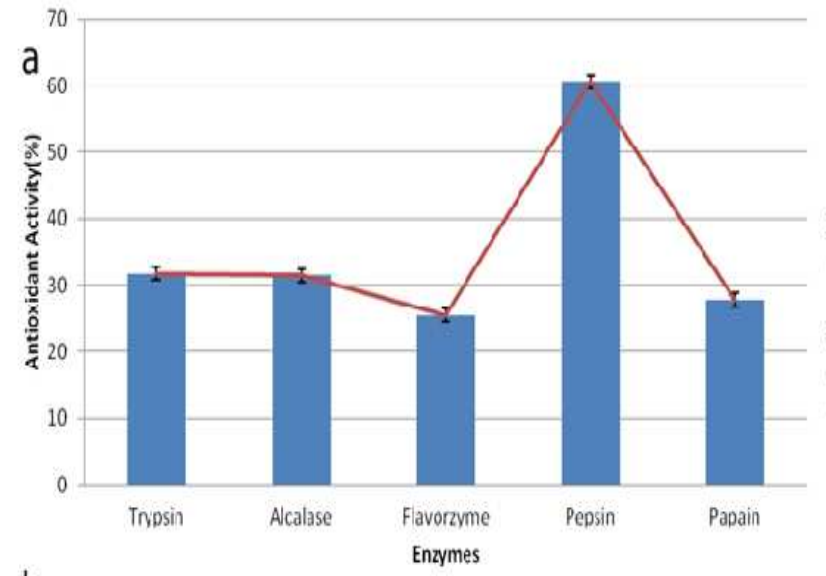

b
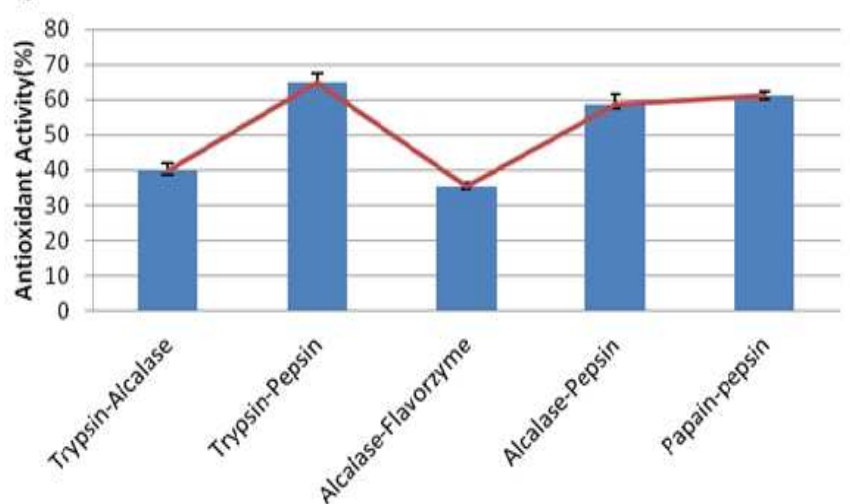

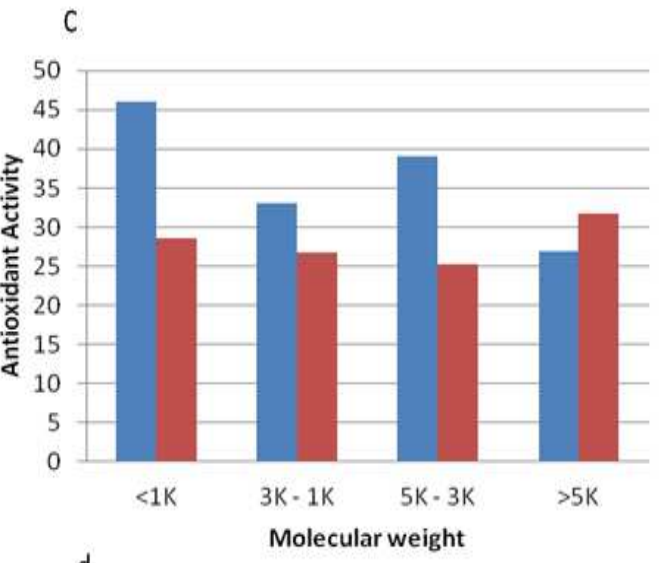

d

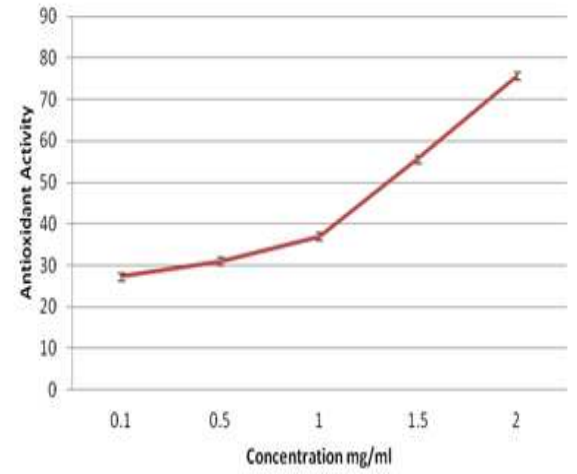

Enzymes

Fig. 1. The DPPH antioxidant activity of lentils hydrolysates by five different enzymes (a), five different enzymes combinations (b), ultrafiltration fractions of Trypsin-pepsin and pepsin (c) and Trypsin-Pepsin hydrolysate in different concentration (d) with controlled conditions.

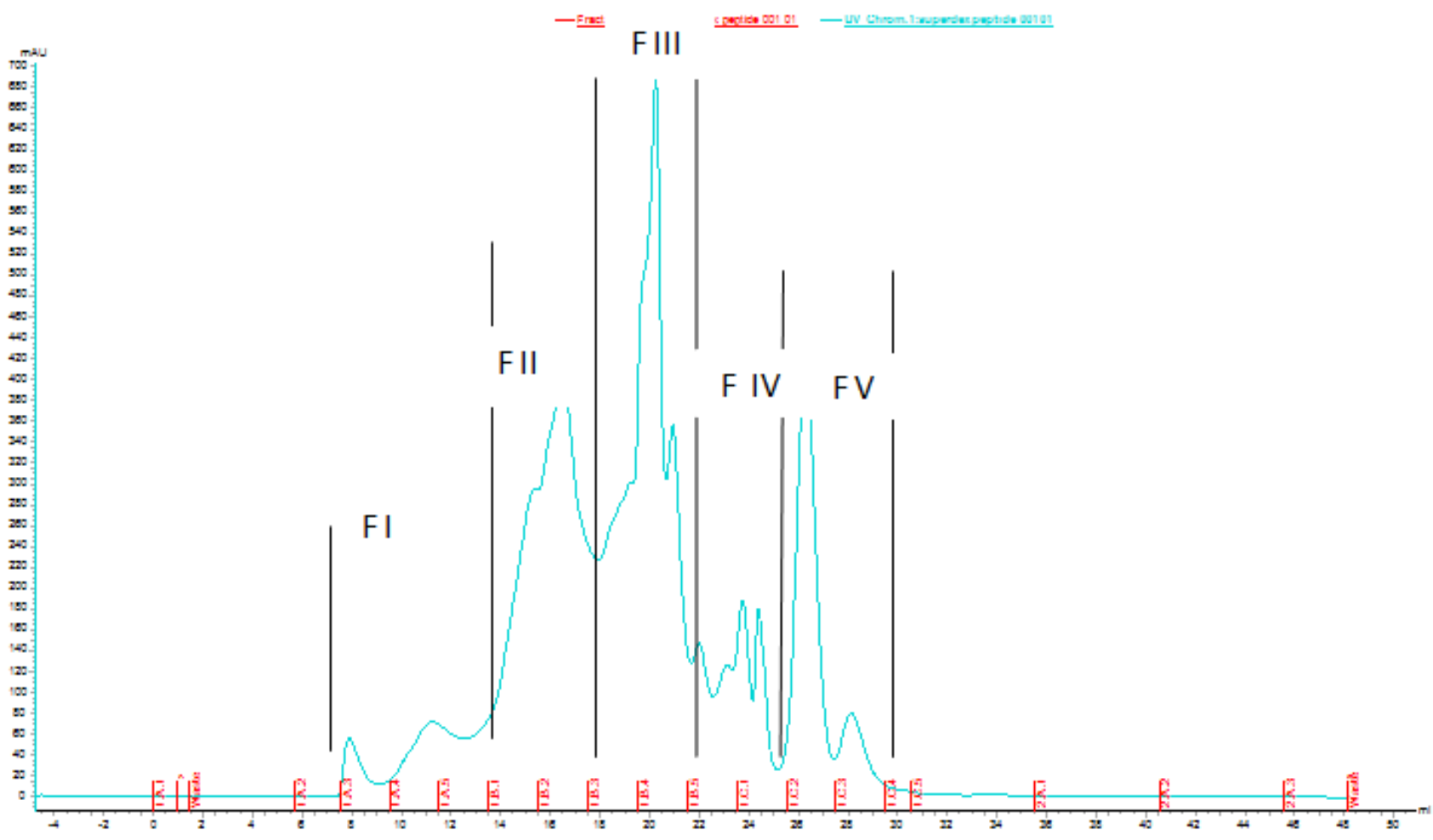

Fig. 3. Separation of antioxidant peptides from Lentils hydrolysate ultrafiltration fraction by Superdex Peptide 10/300 GL, prepacked Tricorn highperformance column for high-resolution gel filtration of peptide by using Akta Pure .Sample was eluted with Tris-HCl Buffer,Ph 7.6 at aflow rate of 0.5 $\mathrm{mL} / \mathrm{min}$ in the $280 \mathrm{~nm}$ wavelength region. Five peptide fractions (Fra.I, Fra.II, Fra.III,Fra IV and Fra V) were obtained according to molecular size. 


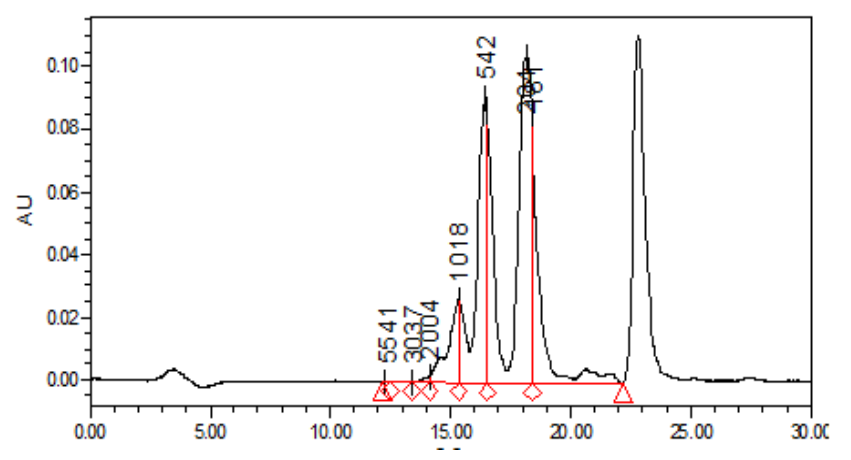

Retention time(min)

Fig. 4. HPLC pattern on a TSK Gel G2000SW $W_{X L}(5 \mu \mathrm{m}, 7.86 \times 300 \mathrm{~mm})$ column of the Fra.III fraction obtained from Superdex Peptide 10/300 GL at $220 \mathrm{~nm}$. The resulting chromatograms contained two major peaks (retaining time 17.6 and $18.4 \mathrm{~min}$ ) corresponding to the target peptide and a number of peaks corresponds to unidentified substances.

\subsection{Antioxidant Activity of Fraction III}

Results for the antioxidant Activity of the lentils fraction III are shown in Table 2. The absorbance was recorded at 2 $\mathrm{mg}$ concentration. The antioxidant activities of Lentils Fraction III were measured in $\beta$-carotene-linoleate model system, reducing power, hydroxyl radical-scavenging and DPPH radical-scavenging activity. As shown in Table. 2, the autoxidation of linoleic acid was $73 \%$.During oxidation, a hydrogen atom was abstracted from the active bis-allylic methylene group of linoleic acid located on carbon-11 between two double bonds. The pentadienyl free radical so formed then attacked highly unsaturated $\beta$-carotene molecules in an effort to reacquire a hydrogen atom. As the $\beta$-carotene molecules lost their conjugation, the carotenoids lost their characteristic orange colour; this process was monitored spectrophotometrically. Unlike laboratorygenerated free radicals such as the hydroxyl radical and superoxide anion, DPPH has the advantage of being unaffected by certain side reactions, such as metal-ion chelation and enzyme inhibition, brought about by various additives [4]. Based on loss of absorbance at the $517 \lambda_{\max }$ for DPPH the Frac III has shown $63 \%$ scavenging activity. The results of the reducing power were weaker than the reference used. The reducing power of bioactive compounds had been reported to be associated with their antioxidant activity [40]. In this assay, the yellow color of the test solution changes to various shades of green and blue, depending on the reducing power of each compound [25].The reducing power assay is often used to evaluate the ability of antioxidant proteins and peptides to donate electrons. In this assay, the ability of lentils fraction III to reduce $\mathrm{Fe}^{3+}$ to $\mathrm{Fe}^{2+}$ was determined. The presence of antioxidants in tested samples results in the reduction of $\mathrm{Fe}^{3+} /$ ferricyanide complex to ferrous form. The reducing power of lentils fraction III has been shown in Table 2. Free radicals with the major species of reactive oxygen species (ROS) are unstable, and react readily with other groups or substances in the body, resulting in cell damage and hence human disease, especially; the chemical activity of hydroxyl radical is the strongest among the ROS. It is easily react with biomolecules such as amino acids, proteins [41].in this study Lentils fraction III has shown $40 \%$ of hydroxyl radical.

Table 2. Antioxidant activity of Lentils Fraction III

\begin{tabular}{ll}
\hline Reducing Power & $\mathbf{0 . 2 8 8}$ \\
\hline Antioxidant activity as determined by $\beta$-carotene-linoleate model & 73 \\
system(\%) & 63 \\
DPPH radical-scavenging activity (\%) & 40 \\
\hline Hydroxyl radical-scavenging activity (\%)
\end{tabular}

\subsection{AKTA Pure Analysis}

For further Purification of the pepsin-trypsin fraction ÄKTA purifier system was employed. After Hiload Superdex Peptide 10/300 GL column separation, chromatograms were recorded automatically as shown in figure 3 . The operations of data collection were driven by UNICORN software which guarantees quick, simple communications between systems and users, and meets the stringent control and data handling procedures of modern laboratories. Five fractions were collected. The fractions were then concentrated and freeze dried. DPPH antioxidant activity was determined for each of the fraction. The activities of the fractions were $23 \%, 30 \%$, $63 \%, 26 \%$ and $41 \%$ respectively. Fraction III was found to show the highest antioxidant activity among all the fractions.

\subsection{HPLC Analysis}

In order to identify the peptides, Fraction III from AKTA pure was subjected to HPLC analysis. Results as presented in Fig 4 showed the chromatographic profile corresponding to the analysis of lentils AKTA pure fraction III.The resulting chromatogram contains two major peaks. The retaining time for the peaks was 17.6 and 18.4 min which corresponded to the target peptide and the unidentified substances.

\subsection{LC Mass Analysis}

The Fraction III was also subjected to LC/MS for the calculated $\mathrm{m} / \mathrm{z}$ values of the different multiply charged fraction III forms. Molecular mass determination has been done for lentils AKTA pure fraction III.The MS spectrum is shown in Fig:5, and the MS/MS spectrum of a single charged ion with anm/zat $540 \mathrm{Da}$ and this is in agreement with findings previously reported on chymotrypsin lentils hydrolysate which had a molecular weight of $<556 \mathrm{Da}$ [32].

Peptides were identified automatically by Masslynx software, Complete LC-MS/MS runs were saved as *.raw files. The peptide mass range was set with the range of 200$1800 \mathrm{amu}$. The precursor ions tolerance and fragment ions tolerance was set to $2 \mathrm{amu}$ and $1.00 \mathrm{amu}$, respectively. The match result gave a putative amino acid sequence: Ala- LeuGly- Pro- Val- Met (587.32Da)

Some authors have previously reported that the antioxidant activity of peptide is the inverse of the molecular weight. This meant that low molecular weight peptide of less than 20 
amino acids has highest antioxidant activity and those less molecular weight peptide can cross the intestinal barrier and exert biological effects(23).

20 biologically amino acids are potentially oxidizable, They contain reactive amino acids containing nucleophilic sulfer-containing side chain (cysteine and methionine) or aromatic side chains (tryptophan, tyrosine, and phenylalanine) and they can also abstracted hydrogen easily. Some chains which contain Histidine are also oxidatively labile. On the other hand, cysteine, methionine, tryptophan, tyrosine, phenylalanine, and histidine, are formed by common oxidation(42).

2

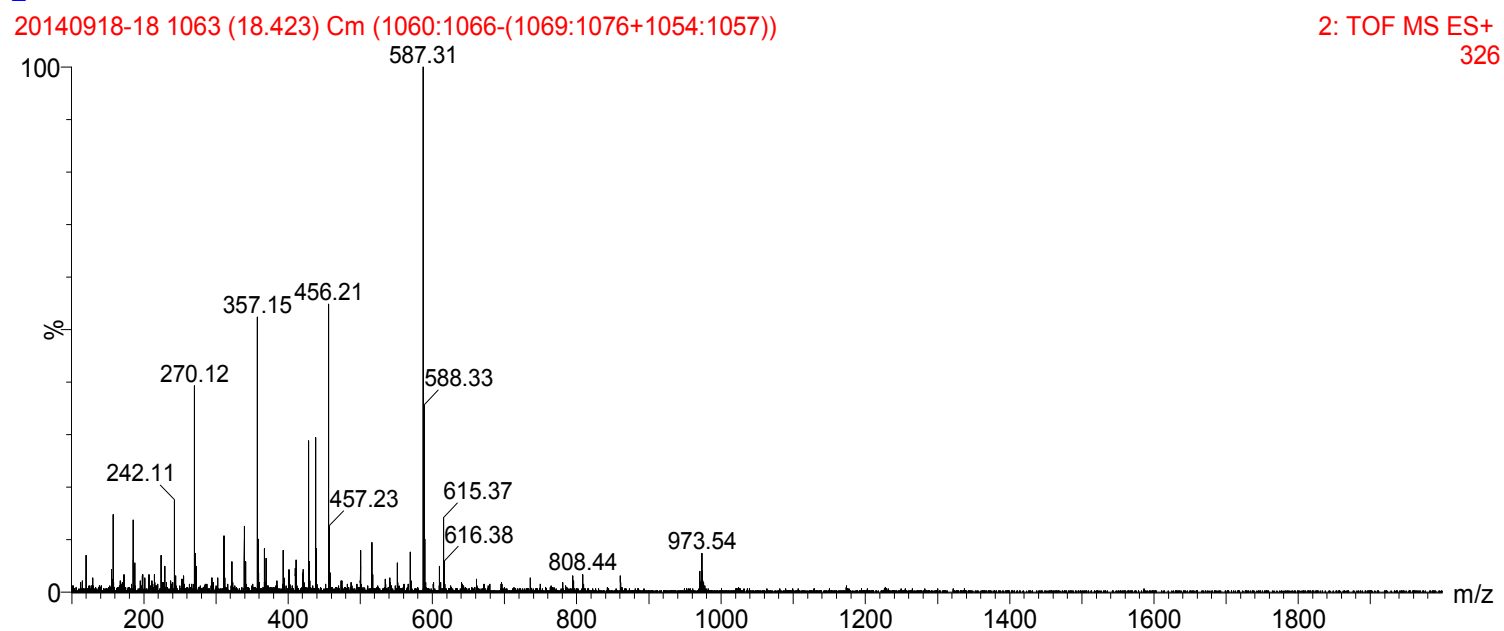

Fig. 5. The MS spectrum of Fraction-III (587.32Da).

\section{Conclusions}

The findings in this study has shown that lentils proteins were effectively hydrolyzed by five enzymes ( Alcalase, Flavorzyme, Trypsin, pepsin, papin ) to obtain peptides with the best antioxidant activities. The purification of the lentils depended on the DPPH radical-scavenging activity .The results of the present work indicated that Fra.III possessed high DPPH radical- scavenging activity and $\beta$-carotenelinoleate model system. By gel permeation chromatography on Superdex Peptide 10/300 GL, the Lentils fraction III antioxidant peptide was purified from Lentils hydrolysates, and the molecular weight and sequence were identified by LC-MS analysis as 587.31 Da and the amino acid sequence was as follows: Ala- Leu- Gly- Pro- Val- Met.

\section{Acknowledgments}

We would like to thank Fatema Zohara for editing the manuscript.

\section{References}

[1] FAO, 2013, http://faostat.fao.org/site/567/default.aspx(Access: 10.12.2014)

[2] Krishna M.Singh and A. K Singh, "Lentils in India: An Overview", 2014.

[3] SS Ali, N Kasoju, A Luthra and A Singh, "Indian medicinal herbs as sources of antioxidants," Food Research International $41,1-15,2008$.
[4] R Amarowicz, I Estrella, T Hernández and S Robredo, "Free radical-scavenging capacity, antioxidant activity, and phenolic composition of green lentil (Lens culinaris)," Food Chemistry 121, 2010, 705-711

[5] A. Djeridane, "Antioxidant activity of some algerian medicinal plants extracts containing phenolic compounds," Food Chemistry $97,2006,654-660$.

[6] Fernandez-Orozco, R; Zieliński and H; Piskuła MK, "Contribution of low-molecular-weight antioxidants to the antioxidant capacity of raw and processed lentil seeds," Nahrung, 2003, 47, 291-299.

[7] [H Han and BK Baik, "Antioxidant activity and phenolic content of lentils (Lens culinaris), chickpeas (Cicer arietinumL.), peas (Pisum sativumL.) and soybeans (Glycine $\max$ ), and their quantitative changes during processing," International Journal of Food Science and Technology 2008, 43.

[8] R Amarowicz, I Estrella and T Hernández," Antioxidant Activity of a Red Lentil Extract and Its Fractions," Int. J. Mol. Sci. 2009, 10, 5513-5527; doi:10.3390/ijms10125513.

[9] Mo'ez Al-Islam Ezzat Faris,Hamed Rabah Takrurimm, Ala Yousef Issa, and Mediterr J Nutr Metab, "Role of Lentils (lens culinaris L.) in human health and nutrition: a review,“ 2013,DOI 10.1007/s12349-012-0109-8.

[10] OP Sharma and TK Bhat, "DPPH antioxidant assay revisited," Laboratory, Indian Veterinary Research Institute, Regional Station, Palampur, India. Food Chemistry 113,2009, 12021205 .

[11] MI Torino, RI Limón and C MartínezVillaluenga,"Antioxidant and antihypertensive properties of liquid and solid state fermented lentils," Food Chemistry 136, 2013, 1030-1037. 
[12] R Agil and F Hosseinian, "Determination of water-extractable polysaccharides in triticale bran," Journal of Food Composition and Analysis, Volume 34, Issue 1, May 2014.

[13] C Barbana, AC Boucher and JI Boye, "In vitro binding of bile salts by lentil flours, lentil protein concentrates and lentil protein hydrolysates," Food Research International $44,2011,174-180$

[14] P Garcia-Mora, E Peñas, J Frias and R Gomez, "High-pressure improves enzymatic proteolysis and the release of peptides with angiotensin I converting enzyme inhibitory and antioxidant activities from lentil proteins," Food Chemistry $171,2015,224-232$.

[15] MA Suliman, AH El Tinay and AEO Elkhalifa, "Solubility as Influenced by $\mathrm{pH}$ and $\mathrm{NaCl}$ Concentration and Functional Properties of Lentil Proteins Isolate," Pakistan Journal of Nutrition 5 (6): 589-593, 2006, ISSN 1680-5194

[16] Christine V. Sapan and Roger L. Lundblad,"Review of methods for determination of total protein and peptide concentration in biological samples," Proteomics Clin. Appl. 2015, DOI 10.1002/prca.201400088.

[17] Li JJ, Hu XQ, Zhang XF, Liu JJ and Cao LS, "Study on variation of main ingredients from spores and fruiting bodies of Ganoderma lucidum," China Journal of Chinese Materia Medica , 2014, 39(21):4246-4251

[18] Bradford. MM, "A rapid and sensitive for the quantitation of microgram quantitites of protein utilizing the principle of protein-dye binding," Analytical Biochemistry 72: 248-254. 1976.

[19] S Nielsen, "Food Analysis Laboratory Manual," ISBN 978-14419-1462-0 e-ISBN 978-1-4419-1463-7, 2010, DOI $10.1007 / 978-1-4419-1463-7$.

[20] B Cabanillas, MM Pedrosa and J Rodríguez, "Effects of enzymatic hydrolysis on lentil allergenicity," Servicio de Alergia, Hospital Universitario 12 de Octubre, Madrid, Spain,2010, DOI 10.1002/mnfr.200900249.

[21] N Saraç and B Şen, "Antioxidant, mutagenic, antimutagenic activities, and phenolic compounds of Liquidambar orientalis Mill. var. orientalis, Industrial Crops and Products" 53 ,2014, 60-64

[22] E Polanco-Lugo and G Dávila-Ortiz, "Effects of sequential enzymatic hydrolysis on structural, bioactive and functional properties of Phaseolus lunatusprotein isolate," Food Science and Technology, 2014, ISSN 0101-2061

[23] X Kou, J Gao, Z Xue, Z Zhang and H Wang, "Purification and identification of antioxidant peptides from chickpea (Cicer arietinumL.) albumin hydrolysates," LWT - Food Science and Technology $50,2013,591-598$

[24] XS Wang, CH Tang, L Chen and XQ Yang, "Characterization and Antioxidant Properties of Hemp Protein Hydrolysates Obtained with Neutrase," Food Technology and Biotechnology, 2009,ISSN 1330-9862.

[25] Y Li, B Jiang, T Zhang, W Mu and J Liu, "Antioxidant and free radical-scavenging activities of chickpea protein hydrolysate (CPH)," Food Chemistry 106 , 2008, 444-450

[26] Laemmli, U. K., "Cleavage of structural proteins during the assembly of the head of bacteriophage T4.Nature," 1970,227, $680-685$.
[27] C Barbana and JI Boye, "Angiotensin I-converting enzyme inhibitory activity of chickpea and pea protein hydrolysates," Food Research International, Volume 43, Issue 6, July 2010, Pages 1642-1649.

[28] YW Chang, I Alli, Y Konishi and E Ziomek,"Characterization of protein fractions from chickpea (Cicer arietinumL.) and oat (Avena sativaL.) seeds using proteomic techniques," Food Research International, 9, November 2011, Pages 3094-3104.

[29] Bertrand P. Chay Pak Ting,"Comparative Composition and Antioxidant Activity of Peptide Fractions Obtained by Ultrafiltration of Egg Yolk Protein Enzymatic Hydrolysates," 2011,1, 149-161; doi: 10.3390/membranes1030149.

[30] YS Chan and TB Ng,"Northeast Red Beans Produce a Thermostable and pH-Stable Defensin-Like Peptide with Potent Antifungal Activity," Cell Biochem Biophys, 2013, 66:637-648 DOI 10.1007/s12013-012-9508-1.

[31] Y Kim, I Dementieva, M Zhou, R Wu and L Lezondra, (2004), "Automation of protein purification for structural genomics," Journal of Structural and Functional Genomics,2004,5:111-118.

[32] M Karamac and A Rybarczyk,"Chymotryptic hydrolysis of lentil meal proteins and characteristics of the resulting hydrolysates, "polish journal of food and nutrition sciences, Pol. J. Food Nutr. Sci. Vol. 58, No. 3, 2008, pp. 351-357.

[33] Pitt JJ. "Principles and Applications of Liquid Chromatography-Mass Spectrometry in Clinical Biochemistry,"The Clinical Biochemist Reviews. 2009,30(1):19-34.

[34] P Rozenfeld and GH Docena,"Detection and identification of a soy protein component that cross-reacts with caseins from cow's milk," Clin Exp Immunol 2002; 130:49-58.

[35] Shewry, P. R., Jenkins, J. A., Beaudoin, F. and Clare Mills, E. $\mathrm{N}$,"The classification, functions and evolutionary relationships of plant proteins in relation to food allergies," In E. N. Clare Mills \& P. R. Shewry (Eds.), Plant food allergens,(pp. 24-41). Oxford, UK: Blackwell Science, 2004.

[36] Marı'a M. Yust,"Production of ace inhibitory peptides by digestion of chickpea legumin with alcalase," Food Chemistry 81, 2003, 363-369.

[37] J Ehren, S Govindarajan and B Morón,"Protein engineering of improved prolyl endopeptidases for celiac sprue therapy," Protein Engineering, Design \& Selection, 2008,vol 21 no. 12 pp. 699-707.

[38] M Wang, C Jia, W Qi, Q Yu, X Peng, R Su and Z He," PorousCLEAs of papain: Application to enzymatic hydrolysis of macromolecules," Bioresource Technology 102 ,2011, 35413545 .

[39] Soo-Yong Kim, Jae-Young Je and Se-Kwon Kim,"Purification and characterization of antioxidant peptide from hoki (Johnius belengerii) frame protein by gastrointestinal digestion," The Journal of Nutritional Biochemistry, Volume 18, Issue 1, January 2007

[40] K Zhu, H Zhou and H Qian,"Antioxidant and free radicalscavenging activities of wheat germ protein hydrolysates (WGPH) prepared with alcalase," Process Biochemistry 41, 2006, 1296-1302. 
[41] JY Je, PJ Park and SK Kim,”Antioxidant activity of a peptide isolated from Alaska pollack (Theragra chalcogramma) frame protein hydrolysate," Food Research International 38, 2005, $45-50$.
[42] Ryan J. Elias, Sarah S. Kellerby and Eric A. Decker,"Antioxidant Activity of Proteins and Peptides" Critical Reviews in Food Science and Nutrition, 2008,Volume 48, Issue 5. 